\title{
China's Belt and Road Initiative and the COVID-19 crisis
}

\section{Peter J. Buckley}

Leeds University Business School, University of Leeds, Maurice Keyworth Building, Leeds LS2 9JT, UK

Correspondence:

PJ Buckley, Leeds University Business School, University of Leeds, Maurice Keyworth Building, Leeds LS2 9JT, UK

e-mail: P.J.Buckley@lubs.leeds.ac.uk

\section{THE BELT AND ROAD INITIATIVE}

President Xi Jinping announced 'One Belt, One Road' in 2013, and the action plan for the Belt and Road Initiative (BRI) was released by the National Development and Reform Commission on March 28,2015 . China thereby undertook potentially the most significant international programme of the twenty-first century (Cai, 2017; Zhang, Alon, \& Lattemann 2018). China's Belt and Road Initiative (BRI) promotes the development of infrastructure along its twin land- and sea-based routes. Infrastructural assets such as railways, airports, ports, roads, telecommunication and electricity grids are vital for a country's economic and social development (Dossani, Bouey, \& Zhu 2020). The BRI's objectives are purported to be in line with the development goals of prospective host countries, but some infrastructure projects implemented have had little regard for the long-term consideration of host-country needs. Even before the COVID-19 pandemic, these problems have already highlighted tensions and fractures between China and several host countries in conceiving, developing and executing BRI infrastructure projects, largely because of the debt burden and related "asset seizures" (e.g. Sri Lanka; Abi-Habib, 2018). Cautionary tales, such as the Khorgos Gateway in Kazakhstan, the "highway to nowhere" in Montenegro (Barkin \& Vasovic, 2018) and the Kyrgyzstan free trade zone, point to the possibility that the anticipated economic and social benefits may not materialize (Economist, 2020a). As noted below, infrastructural projects rely on inducing productivity gains in the host country to produce net benefits, and are primarily debt-financed. All existing systems will suffer from post-crisis hysteresis, the effects of the virus remaining long after the immediate crisis is past. All institutions and institutional characteristics depend upon the history and the status of their systems. The BRI is no exception, and the initiative will be profoundly affected by the ravages of the virus and its aftermath. Adaptation is nonetheless possible. The BRI may be able to switch to the modernization of rail, ports and airport links and focus more on telecommunications. 


\section{CORONAVIRUS: IMMEDIATE IMPACT ON BRI}

Coronavirus represents both a demand and a supply shock to the global economy. The key question is which assets are exposed most to shock and to the associated volatility? The BRI focuses largely on physical infrastructure that is declining as a priority. The shock has produced a significant stimulus to digital versus physical connectivity. The need for physical infrastructure declines where digital connectivity can substitute for physical contact. In addition, disruptive innovation including 3-D printing has produced a bias toward localization. The increased use of digital communications technology has given rise to "firms from nowhere". Virtual reality, AI, and robotics all provide scope for the reduction of person-to-person contact. The largest effects are likely to be on trends that were happening anyway, including rationalizing global value chains (GVCs), decoupling from China, building flexibility (and alternative locations) into GVCs, holding more inventory and other forms of insurance against hold-ups and breakdowns, and localization. The effects of "working from home" will also have a negative impact because infrastructure depends largely on "working on site". The "market for market transactions" (Liesch, Buckley, Simonin, \& Knight, 2012), already under pressure before the virus hit, faces permanent shrinkage.

Some host countries, and indeed China, may react to the downturn by seeking to cancel BRI contracts (Economist, 2020b). The nature and content of the contracts that make up BRI are opaque and clouded in secrecy. Even the IMF was unable to get full access to the China-Pakistan Economic Corridor agreements when Pakistan was applying for an IMF loan. Consequently, much of the contractual detail can only be subject to conjecture. However, the crisis has put many of these agreements under threat. Material adverse change clauses provide a buyer with the right to terminate a sale and purchase agreement if the target business or company is materially and adversely affected by events occurring between a specified point in time and the intended completion date. If such clauses exist in BRI agreements, then coronavirus would be such a material adverse change. Where host countries have entered into resource-backed loans, the structure of the contract (based on quantity or price) is crucial. Chinese banks (and non-bank SOEs) are primary lenders of resource-backed loans. The ability of host countries to assume debt or to pay off loans is compromised by the crisis, and the willingness of China to assume the burden in the post-crisis world is untested (Kynge \& Yu, 2020).

A new and uncertain additional factor is the extent of the post-crisis backlash against China, motivated by geo-political rivalry, trade tensions, intellectual property disputes, and assertions of non-transparency in the disclosure of the origin and spread of the virus. The Japanese Government is to extend loans to Japanese companies operating in China to relocate back to Japan, and even to third countries. This backlash comes on top of the extensive relocation of activities away from China, particularly by US firms under domestic political pressure. Coronavirus has disrupted supply chains, and, to reduce risks, shorter and purely intraregional or domestic value chains will be preferred. In addition, host countries, including EU countries, are likely to protect themselves from Chinese takeovers of key firms by buying shares or introducing "golden shares" held by state bodies. Again, we should beware of blanket conclusions - viable supply chains excluding China may be difficult and costly to build, and the impact by sector will vary.

\section{MEDIUM-TERM IMPACT OF CORONAVIRUS ON BRI}

The medium-term effect will depend greatly on the flexibility that China is able to build into the BRI. Its attempts to pivot to a "digital silk road" and a "health silk road" are crucial (El Kadu, 2019; Wheeler, 2020; Dutta, 2020). The digital silk road will bring about increasing conflict over the global governance of the internet. In assessing the efficacy of any infrastructure investment, it is essential to note that the benefits to the host economy are indirect. An infrastructure investment pays off when it increases the productivity of the host economy. Most infrastructure projects are debtfinanced. User charges (fees, tolls, etc.) do not usually repay the initial investment. A successful infrastructure investment generates sufficient productivity gains in the economy such that a proportion of these gains can be appropriated (usually by the host government) to pay off the debt. Where this does not occur, investment in ports, roads, rails, energy, water and other infrastructural projects results in a 'debt trap'. If the project is largely foreign government-funded - as is the case of the BRI - then this debt will be repayable in foreign 
exchange, thus burdening the host economy that has to earn the foreign exchange to repay the debt. This deficit can then lead to perceptions, or the actuality, of a failed infrastructure project.

The BRI is massively dependent on the international transfer of Chinese personnel and managers to its projects. This was a major point of criticism in the pre-virus world. It has limited the direct employment of local personnel and the spill-over gains to the host country. During the peak COVID19 crisis period, and in the aftermath of the virus, it is untenable. The ability of the BRI to switch to digital versus personal contact in the implementation of its projects will be a major challenge, and construction is notoriously difficult to depersonalize. The opacity of contracts and the associated corruption will be increasingly challenged in the resource-scarce, depressed world economy of the recovery period. There will be a sharper focus on the costs and benefits of the BRI: the investigation of productivity and spillover benefits will be more forensic, as host countries examine the totality of their public expenditure, particularly as against the benefits of spending on public health. Excessive debt is also a possibility for poor host countries with limited capacity to pay back the debt. The type of infrastructure that will be welcomed post-crisis is "soft infrastructure" - institutions that help to maintain the economy that rely on human capital and services, including healthcare, financial systems, education systems, law enforcement and government (both national and local) services delivered direct to the public (planning, licenses, library and other personal services). All these rely on personal contact, all are politically and culturally sensitive, and, largely, China lacks leadership in these areas.

If China perceives the political benefits of continuing support for BRI, then the "fringe benefits" to the host country may be increased (handouts, favors, education grants, donations) in order to increase bargaining power versus the West, but such expenditure must attract increasing scrutiny at home as well as internationally. The debt burden of supporting business may overwhelm future debtfinanced foreign expenditure on infrastructure.

The medium-term impact of the virus will be to exacerbate pre-existing trends. The use of foreign projects under BRI utilizes overcapacity, particularly in SOEs, and staves off the need to reform. The lack of transparency in China shows in the opacity of BRI contracts. As competitive bidding is unusual in BRI contracts, their terms are unknown. Chinese domestic problems influence the strategy of the BRI, including the need to connect lagging regions (e.g. Xinjiang), the difficulties in reforming the domestic finance and banking system, and the extent of debt at all levels of government. Pre-virus, there was domestic pressure to spend at home, not abroad. The domestic political tasks facing the Communist party were already huge; now, they are critical.

\section{POTENTIAL LONGER-TERM REPERCUSSIONS OF THE IMPACT OF CORONAVIRUS ON BRI}

The virus puts pressure on extended global supply chains. Already, the export proportion of value chains was declining and higher value-added activities were increasingly "reshored" in home countries (Moser, 2019). The environmental problems of extensive new infrastructure projects have ben subject to intense criticism. Human rights violations in China and in several recipient client states are well documented. However, the BRI is an amorphous concept and is capable of reform. There are signs of this happening - the switch to digitaland health-based infrastructure has begun, but is untested and will be contentious. It has become mutable because China is willing to rethink BRI strategy in the face of 'pushback'. It was also designed as a long-term (35-50 years) initiative (Enderwick, 2018). The BRI represents a large-scale shift in the multilateral regime - the focus of BRI is largely bilateral, not multilateral - and these significant changes mean that business can longer take the global institutional framework as given. A renewed focus on the global trade and investment regime will be required post-virus.

\section{CONCLUSION}

In the absence of significant domestic economic reform, the potential increase in overcapacity following the downturn, particularly in SOEs, will increase the pressure on Chinese firms to export overseas, and this could boost the BRI. Moreover, many of the BRI host countries lack adequate health provisions in the face of COVID-19. China's "health diplomacy" in supplying medical equipment may tie these countries closer to China. However, China's domestic unemployment in the slump is going to be an immense problem, particularly in cities and among migrant workers. The dislocation caused by the phased lockdown may be semi-permanent in its effects, especially given the 
desire of individual provinces to protect themselves from re-infection. Increases in unemployment could lead to increasing social unrest and demands to spend at home in China, not abroad. The debt burden of the impact of the virus to deal with its depredations to the economy and society may provoke a rethink in taking on further BRI debt and underwriting the concomitant debts of SOEs. It is even possible that China will call in some debt repayments for existing BRI commitments.

The crisis has shown the ability of societies to function with decreased physical connectivity that is the key benefit of BRI. As physical globalization recedes, digital globalization will continue to grow, but this will bring enormous challenges over governance of the internet. A refocusing, at the very least, will be essential if the BRI is to meet its objectives. The more grandiose, politically motivated "trans-continental" links could be re-evaluated as wasteful "white elephants", but connectivity between resources and transport hubs (rail hubs, airports, ports) may retain value as trade (hopefully) recovers. The threats to the continuation of the BRI post-crisis call into question the capacity and capability of the Chinese state to

\section{REFERENCES}

Abi-Habib, M. 2018. How China got Sri Lanka to cough up a port. New York Times. 25 July 2018.

Barkin, N., \& Vasovic, A. 2018. Chinese "Highway to Nowhere" Haunts Montenegro. London: Thomson-Reuters. 16 July 2018

Cai, P. (2017). Understanding China's Belt and Road Initiative. Sydney: Lowry Institute for International Policy.

Dossani, R., Bouey, J., \& Zhu, K. 2020. Demystifying the Belt and Road Initiative. RAND Working paper WR-1338, Santa Monica, CA: RAND Corporation.

Dutta, A., 2020. Roundtable: Introduction to China's digital silk road: economic and technological implications. Asia Policy, 15(1).

Economist. 2020a. Special Report: China's Belt and Road. 8 February.

Economist. 2020b. The Belt and Road Initiative: Break time. 6 June: 50-51.

El Kadu, T. H. 2019. The promise and peril of the digital silk road. London: Chatham House.

Enderwick, P. 2018. The economic growth and development effects of China's One Belt, One Road Initiative. Strategic Change, 27(5): 447-454.

Kynge, J, \& Yu, S. 2020. China faces wave of calls for debt relief on "Belt and Road" projects. Financial Times, 1 May.

Liesch, P. W., Buckley, P. J., Simonin, B. L., \& Knight, G. 2012. Organizing the modern firm in the worldwide market for market transactions. Management International Review, 52(1): 3-21. continue to increase incomes, employment and wealth at home while sustaining a major foreign economic power projection initiative at the same time.

Two key questions remain. Will the trade-offs be politically acceptable both at home and to the international community? And can the BRI combine resilience with connectivity? (Not simply resilience in the face of "black swan" events such as coronavirus, but also with respect to climate change and domestic and global societal challenges).

The BRI, in common with many other preCOVID-19 institutions, will require radical reappraisal in the new, post-crisis, world.

\section{ACKNOWLEDGEMENTS}

I would like to thank Giles Blackburne, Jean-Marc Blanchard, Ryan Tang, Hinrich Voss and Hussain Rammal for comments on an earlier version and an anonymous referee, Ari Van Asshe and Sarianna Lundan for comments.

Moser, H. 2019. Reshoring was at record levels in 2018. Is it enough? Industry Week, 8 July.

Wheeler, A. 2020. China's Digital Silk Road (DSR): The new frontier in the digital arms race. Hong Kong: Deza Shira and Associates Silk Road Briefing.

Zhang, W., Alon, I., \& Lattemann, C. 2018. China's Belt and Road Initiative: Changing the Rules of Globalization. London: Palgrave.

\section{ABOUT THE AUTHOR}

Peter J. Buckley OBE, FBA, is Professor of International Business, Founder Director of the Centre for International Business, University of Leeds (CIBUL). Founder Director of the Business Confucius Institute at the University of Leeds and Cheung Kong Scholar Chair Professor in the University of International Business and Economics (UIBE), Beijing. President of the Academy of International Business, 2002-2004.

Publisher's Note Springer Nature remains neutral with regard to jurisdictional claims in published maps and institutional affiliations.

Accepted by Sarianna Lundan, Editor-in-Chief, 19 June 2020. This paper is part of a series of contributions dealing with the implications of the COVID-19 pandemic on international business policy, and it was single-blind reviewed. 